\title{
Lumen
}

Selected Proceedings from the Canadian Society for Eighteenth-Century Studies

\section{Painting and Poetry: Titillation and Translation - Diderot confronts Lucretius's Invocation to Venus}

\section{Moishe Black}

Volume 15, 1996

URI : https://id.erudit.org/iderudit/1012471ar

DOI : https://doi.org/10.7202/1012471ar

Aller au sommaire du numéro

Éditeur(s)

Canadian Society for Eighteenth-Century Studies / Société canadienne d'étude du dix-huitième siècle

ISSN

1209-3696 (imprimé)

1927-8284 (numérique)

Découvrir la revue

Citer cet article

Black, M. (1996). Painting and Poetry: Titillation and Translation — Diderot confronts Lucretius's Invocation to Venus. Lumen, 15, 27-35.

https://doi.org/10.7202/1012471ar d'utilisation que vous pouvez consulter en ligne. 


\section{Painting and Poetry: Titillation and Translation - Diderot confronts Lucretius's Invocation to Venus}

The theme of the CSECS conference in 1994 was 'Reason and Unreason.' In a dozen ways, in a dozen works, Diderot's stance, on reason and its opposite, consciously reflects the stance found in Titus Lucretius Carus's didactic poem De Rerum Natura.

Reason, for instance, is a rational discourse, in Latin ratio. 'I will set out to discourse to you,' says Lucretius (De Rerum Natura, Bk I, 11. 54-55). ${ }^{1}$ 'What I am going to write about is ...,' says Diderot. Well, what? In both cases, the whole external world. '[About] the workings of nature,' says Lucretius (I, 148). 'What I am going to write about is nature,' says Diderot (vol. II, p. 9); ${ }^{2}$ and, aware of boldly going where Ro-man has gone before, he opens these Pensées sur l'interprétation de la nature with an epigraph from Lucretius. ${ }^{3}$ Unreason, on the other hand, implies giving up on that rational process as a road to truth. 'If you surrender your judgment at any time, [you] will want to desert our ranks,' Lucretius warns his pupil (DRN I, 102-03). 'If I renounce my ability to reason,' Diderot warns his reader, 'I no longer have anything to guide me' (Pensées philosophiques, D. I, 159).

Reason is logic, unreason illogic. There must logically be, argues the Roman poet, smallest particles of matter. Otherwise 'even the smallest bodies will consist of an infinite number of parts.' Such thinking 'true reason cries out against' (I, 615-16 and 623). For the philosophe likewise, 'an element in this state of ultimate division is absolutely indivisible, since further division ... is just a concept,' with no basis in reality (Interpr. nat., D. II, 56). These smallest particles form the atoms, out of which both men build the visible world. ${ }^{4}$

Reason is belief in cause and effect. Things do not just happen by themselves, nor at the whim of a god. 'Nothing can be created out of nothing,' assures the disciple of Epicurus (I, 155-56), and Diderot agrees: there is no such thing as 'an event absolutely unrelated to any other' (Interpr. nat., D. II, 15). 
Unreason is fear, the fear which results from thinking that things do happen arbitrarily, that gods do meddle - gods who seek to punish you, if not now then after you die. We are 'haunted by the fear of eternal punishment after death,' wrote the Latin thinker (I, 111). 'We would be quite at peace in this world,' echoed the French thinker, 'if we could be quite sure we have nothing to fear in the next' (Pensées phil., D.I, 130).

Echoed the French thinker? That was how it struck Voltaire. Voltaire read the French words whose translation was just cited and, in the margin of his Diderot, jotted from memory the Latin words. For of them all, in a French Enlightenment drawing considerable support from antiquity, Diderot was the most imbued with Lucretius's poem on the nature of things.

The conference paper of which this is a printed version proposed to examine one small corner of the extensive topic 'Diderot and Lucretius': from the 7400 verses of De Rerum natura, Diderot's reaction just to the opening lines. ${ }^{5}$ It emerges that the Frenchman is imbued as much with Lucretius's poetic medium as with his materialist message; it emerges also, that to present reason and unreason in opposition as was done above, while valid in some contexts, is inappropriate in others.

That first bit of De Rerum natura is commonly called the Invocation to Venus. In it, Lucretius asks the goddess for help: since she is alma Venus, all-nourishing Venus, filling living things with the charm of desire so that they will reproduce, let her fill the poet's words with that same charm, and then let her go on to charm personally the god Mars, so that Rome will have peace, allowing a certain Memmius to turn from studying war to studying the teachings in De Rerum natura. ${ }^{6}$

Today's reader may be surprised that a poet setting out to teach how our world came into being from random collisions of atoms, and how it runs on the same principle with no divine intervention, should ask the help of a goddess, especially a goddess who fosters creation or at least procreation. The contradiction is, in fact, only apparent: the creative forces which Lucretius here calls 'Venus' he will later call 'nature,' and the Invocation, as the classicist Sikes assures us, is just a conventional literary device. ${ }^{7}$

Certainly Lucretius's fellow determinist, Diderot, has no qualms about the presence of a goddess; he simply takes this opening passage for what it is: gorgeous poetry, in fact - as poetry - his favorite passage in the entire poem. Repeatedly he enthuses over the Invocation, quotes from it, translates what he has quoted, uses the passage to define his esthetic theory. As already suggested, Diderot's writings are shot through with Lucretian influence, but his three longest overt references to Lucretius - overt in the sense that the Roman writer is named, quoted or discussed - derive from the Invocation to Venus. They occur in Essai 
sur le mérite et la vertu (a translation of Shaftesbury, 1745), Observations sur l'Art de Peindre, poème par M. Watelet (1760) and the Salon de 1767.

Two segments of the 43-line Invocation attract him particularly: the first four lines, in which Venus by herself gazes down on creation, and eleven lines a little further on, where the poet imagines her turning on the charm to, as it were, outgun the God of War.

What is so special for Diderot about these two sub-passages? Mainly, they embody for him what poetry can do, and to some extent what painting cannot. For one thing, poetry has greater visual scope than its sister art. Reviewing paintings at the Salon, the official biennial art exhibition, of 1767, Diderot came to one he did not like: Le Dauphin mourant, Death of the Crown Prince, by La Grenee. ${ }^{8}$ The critic finds this canvas cluttered with people and symbolic objects, all flat, the eye of the beholder not knowing what to look at. There are the dying heir to the throne on a bed revealed by a raised curtain, his wife seated by his side in an armchair, one of their sons with his head in her lap, another standing at the foot of the bed, a third, who had in fact died earlier, ${ }^{9}$ hovering in the air over his father, an allegorical France standing at the foot of the bed, to say nothing of a crown, a sphere and books. What is wanted, according to the philosophe, is a medium offering more space. Poetry, for instance, such as is found in Lucretius:

To give us a measure of relief from the narrow confines of La Grenée's composition, [writes Diderot], let me cite an ... example to show that the greatest word picture I have ever found in a poem would make a mighty awkward subject for a painter, even one who had a ceiling or gallery to work with. Lucretius has said:

Aeneadum genitrix, hominum divumque voluptas,

Alma Venus, coeli subter labentia signi,

Quae mare navigerum, quae terras frugiferentes

Concelebras.

Lucretius, De Rerum natura, lib. I, v. 1 et seq.

Diderot now offers a French adaptation, and I am translating Diderot not Lucretius:

"Mother of the Romans, enchantress of men and gods, from the heavens where the stars roll overhead, you see beneath your feet the seas which bear our ships and the lands which yield our harvests, and over them you spread fecundity."

It would take a wall [Diderot continues], a building a hundred feet high, to do justice to the immense sweep of this passage ... Do you think a painter could hope to capture ... the goddess in all her majesty? What will he do about those vast seas which bear our ships...? (Salon de 1767, D. XI, 77-78.) 
Besides being able to do more with space than painting can do, poetry can also do more with time. Diderot was fascinated by the problem of a painter depicting an event but forced by the medium to choose one moment for looking in on the scene. Those people in La Grenée's canvas are acting or reacting - the dying man is dying, the dead child is encouraging him (for a crown of immortality awaits), a living child is being comforted, France is (we are told) already brooding on the imminent death of the Dauphin's wife ${ }^{10}$ - all concurrently. It would be a help to have a changing picture. Once again, enter Lucretius:

I must show you [Diderot says] how a poet, in a few short lines, presents a succession of several distinct moments in time.... [He quotes the entire VenusMars portion of the Invocation:] Effice, ut interea ... [and presents a French version; I again am translating Diderot:]

Meanwhile, oh Venus, bring about an end to the raging fury of war, on land, on sea, and all throughout the world; for you alone can bring peace to us mortals; for yours is the embrace the terrible god of battles seeks out as respite from his labours; yours the arms that clasp him as he falls, held fast by an arrow whose wound is everlasting.

When he has rested his head upon your lap, he fixes you with his greedy gaze; he looks at you and is intoxicated; his mouth is half agape and his soul seems to hang suspended from your arms.

Take that instant when your sacred limbs support his weight, bend tenderly over him, enfold him in your celestial body, and pour sweet persuasion into his heart. Speak, goddess! And let Rome, thanks to you, know peace and calm.

\section{Diderot now analyzes:}

First moment in time, first picture: Mars, weary of carnage, is casting himself into Venus's embrace.

Second moment in time, second picture: the god is resting his head on the goddess's lap, and he is drinking intoxication from her gaze.

Third moment in time and third picture: the goddess, bent tenderly over him and enfolding him in her celestial body, is speaking to him and asking him for peace.

Come now, my dear fellow, isn't that more enjoyable than listening to me explain how this composition of La Grenée's looks just like a commemorative plaque and is about as exciting? (Salon de 1767, D. XI, 76-77.)

Chouillet states that the connecting thread in Diderot's esthetic thought is 'the search for unity' between the arts. ${ }^{11}$ I prefer to speak of interidentity, not several discrete arts linking up somewhere, but one 
protean phenomenon, art, able to assume several guises, making it perfectly natural for both the time and space problems in La Grenée's canvas to be explicated by examples from Lucretius's poem. In the shifting world of Lucretian atoms, adopted by Diderot and applied in ways the Roman never thought of, one art becomes another.

There is also, in Diderot's appreciations, a considerable suggestion of inequality, in favour of the poetic medium. Poetry can extend the range of vision further, provide a further dimension (time). The philosophe quotes, elsewhere in this same critique, Horace's 'Ut pictura, poesis erit, ${ }^{12}$ but only to emphasize the notion of inequality. For poetry to 'be like a picture' is no problem, he says in essence; anything painting can do, poetry can do. What is not true for him is the converse statement. Chouillet appears to have passed by the Dauphin mourant criticism with its implication that for Diderot one of the guises of art, poetry, may be inherently superior.

The Dying Prince is by no means the only occasion for Diderot to cite Lucretius's Invocation when discussing esthetics. Earlier, he had used both sub-passages - Venus and Venus-Mars - to bolster the very basic contention that Beauty itself, and consequently an absolute standard of Beauty, do indeed exist. Lucretius's lines are so enduring, says the Frenchman, that they almost give the lie to Lucretius's philosophy of a transient universe (Mérite et vertu, D. I, 33, n. 2). And indeed, where the transient universe, changing as the atoms recombine, is for Lucretius a given, so that he merely seeks in poetry the best way to convey that teaching (hence his sincere plea for Venus, or poetic inspiration, to lend charm to his verses), ${ }^{13}$ Diderot's reaction (the medium is so beautiful it belies the message) reveals Diderot's own ambivalence: all his life he was torn, his head telling him Lucretius's materialism was correct, his heart longing for absolutes and permanence, in art and in every domain.

As for La Grenée, at the next art Salon he was so ill-advised as to exhibit a Venus and Mars Taken Unaware by Vulcan. Diderot demolishes this new effort in one scathing paragraph: your Mars looks like a fortyyear-old transvestite woman, he apostrophizes the artist, and your Venus simply cannot compare with the one in Lucretius (Salon de 1769, D. XI, 401).

But humanity lives not by esthetics alone. If Diderot is especially fond of the Venus-Mars seduction scene, that is partly because it is a seduction scene.

This time Lucretius is the ambivalent one. As an Epicurean he preaches non-involvement in the moils and toils of physical love, since involvement interferes with the quiet life. Yet several parts of the poem suggest that he knows whereof he speaks. Diderot, in contrast, is of one mind about sex: he's for it. When his contemporary Watelet wrote a 
poem containing an Invocation to Venus, Diderot complained that by comparison with Lucretius's version, the French one had 'no poetic images, no scenes' (Art de Peindre, D. XIII, 17). An attentive reading, however, brings out Diderot's real complaint: what Watelet's Invocation has is no sex.

And if the philosophe, who normally digests Lucretian thought and subtly transmutes it into Diderot, chooses to quote the Venus-Mars lines directly and to translate them not once but twice ${ }^{14}$ (to say nothing of summarizing them in his moments-in-time review), it is of course partly because here he is dealing with the poetry not the ideas, but surely also because he is revelling in their sexual content, pleasuring himself with words as he so often does, and even in one of his translation-adaptations causing Venus to send, as it were, hormones flowing through the veins of Mars, which in Lucretius's original she did only for the birds and the bees.

There are other circumstances surrounding Diderot's expressed liking for the Invocation, circumstances themselves Lucretian, as though all roads were leading back to the Roman poet.

A first example concerns Diderot's quoting from the Invocation in order to prove that Beauty exists (see above). This he does in a footnote to his translation of the essay by Shaftesbury. The footnote is not in the original English text; it is Diderot's gratuitous addition. Not entirely gratuitous, however, for Shaftesbury's essay itself contains a reference to 'atoms and Chance,' along with passages strongly reminiscent of Lucretius's diatribes against religious superstition.

The comparison of Le Dauphin mourant and the Invocation is not isolated either: Diderot's series of criticisms for that year's art exhibition abounds in Lucretian references. His friend De la Grange was working on a complete translation of De Rerum natura which appeared the following year. Diderot was lending a hand, so that at the time of the 1767 Salon his head would have been full of Lucretius. ${ }^{15}$

There was yet another relevant circumstance: Diderot's hostility to the canvas of the Dying Prince was conditioned by his hostility to the man who commissioned it, the duc de la Vaugyron. The Duke had been a tutor in the late Prince's household, and according to the philosophe, the Dauphin had let de la Vaugyron 'poison the hearts and minds of his [the Dauphin's] children with bigotry, jesuitry, fanaticism and intolerance' (Salon de 1767, D. XI, 62) ${ }^{16}$ Now, if there is one non-contemporary name automatically associated with the hatred of the French Enlightenment for fanaticism and intolerance, it is that of Lucretius, whose famous description of Iphigenia being ritually sacrificed, ending with the muchquoted 'Such are the heights of wickedness to which men are driven by 
superstition,' follows the Invocation to Venus at an interval of some 40 lines. ${ }^{17}$

So: the Shaftesbury essay with the Venus-Beauty footnote happens to be Lucretian in flavour itself; the painting that falls short of Lucretius's Venus happens to be from a year when Diderot's art critiques are full of Lucretian references and when a translation of De Rerum natura is in the works; and the man who paid for that painting happens to be the kind of religious bigot Diderot joined Lucretius in hating. When these peripheral factors are added to what we have seen of Diderot's esthetic judgments, his quotations and translations, a web of fascination on his part is formed, with the opening of Lucretius's poem at the center of the web. And yet, of deeper significance than all this, is the manner in which Diderot apprehends the Invocation. I offer the following ratio comparing what Lucretius says and what Diderot is:

First, the Latin thinker. In Lucretius's cause-and-effect world, even the emotions are materially engendered. 'Mind and spirit are both composed of matter' (DRN, III, 161-62). Each person's mind is a different combination of air, warmth, wind and a subtle fourth ingredient 'whose component atoms are smaller... This it is that first sets the sensory motions coursing through the limbs... Then everything is roused to movement: the blood is quickened; ...bones and marrow are thrilled with pleasure or the opposite' (III, 244-251). And emotions in turn lead to verbalizing: 'If the animals ... are impelled by different feelings to utter different cries, how much the more reason to suppose that [early humans] had the power of ... distinctive utterances!' (V, 1087-1090). From atoms, Lucretius has taken us via sensations and emotions to rational expression.

I invite comparison of this logical progression with the way in which the philosophe appreciates the four Venus lines, not what he says about them but the steps culminating in his saying it:

It would take a wall, a building a hundred feet high, to do justice to the immense sweep of this passage, which ... no one before me has ever sensed. Do you think a painter could hope to capture that ... crown of blazing globes wheeling about the goddess's head? (Salon de 1767, D. XI, 78.)

This quotation from Diderot which includes portions omitted earlier, shows how the stimulus of the poetry has produced in the critic a reaction both felt and sensed - 'no one before me has ever sensed,' the French sentir covering both the sensory and the intuitive - leading in turn to the emotion of enthusiasm: 'it would take a wall [!], a building a hundred feet high [!],' and eventually to an articulate formulation: for this or that reason, no painter could hope to do what the poet has done. 
In short, what the Roman writer taught, the French writer, in his way of apprehending the universe (here, a poem), embodied. For both writers, if unreason be emotional reaction and reason rational discourse, these are not opposing phenomena but rather part of a sequence in the unified nature of things.

\section{MOISHE BLACK}

University of Saskatchewan

\section{Notes}

1 For quotations from Lucretius I have used Ronald Latham's translation: Lucretius, On the Nature of the Universe (London: Penguin, 1951).

2 Quotations from Diderot, including his French adaptatons of Lucretius, have been translated by me. They are based on J. Assézat, ed., Oeuvres complètes de Diderot, 20 vols. (Paris: Garnier, 1875-77). The letter D. is followed in each case by the relevant volume number in the Oeuvres complètes.

3 The epigraph in Diderot (D. II, 9) reads 'Quae sunt in luce tuemur/ E tenebris,' a slight misquotation of De Rerum Natura IV, 337, 'E tenebris autem quae sunt in luce tuemur,' 'When we are in the dark we see objects that are in the light.'

Lucretius is discussing optics; Diderot's out-of-context borrowing gives the lines a metaphorical value implicit in the word 'Enlightenment.' This is one of a hundred interrelated ways in which Diderot and his age hark back to the Latin poem.

4 'Form the atoms,' not 'are the atoms.' Commentators have not hitherto understood that Lucretius's system really does include sub-atomic particles.

5 There exists a substantial corpus of critical writing on or including the topic of Diderot and Lucretius - the reader is referred for instance to J.W.

Schmidt,...Lucretius' Legacy in Diderot's ... Thought (Studies on Voltaire 208), J. Roger, Les Sciences de la vie au XVIIIe siècle (Paris: Armand Colin, 1963), or I. Smith, 'Le Rêve de D'Alembert and De Rerum Natura' (AUMLA 1959) - but no full separate treatment, so far as I know, of Diderot's multi-facetted involvement with the Latin poem's opening segment. The literature rarely makes sustained comparisons of Diderot's actual words and Lucretius's actual words, a method used here and which I am presently extending to all of DRN Book I. Even for the opening lines, the present conference-length communication presents only a portion of what such an approach brings to light.

6 Little more is known about the noble politician Gaius Memmius than is contained in this sentence. Aside from the opening invocation, the entire poem is addressed to him; his real function therein is to provide a 'you' for Lucretius to argue with.

7 E.E. Sikes, Lucretius, Poet and Philosopher (Cambridge: Cambridge U P, 1936) 117.

8 The full name of the painting is Le Dauphin mourant, environné de sa famille. Le Duc de Bourgogne lui présente la couronne de l'immortalité. (The dauphin, dying, in the midst of his family. The Duke of Burgundy is presenting him with the crown of 
Immortality.) The Dauphin, son of Louis XV and Marie Lecinzka, had died in 1765, two years before the Salon. Jean-Louis-François La Grenée (1724-1815) is described by the Petit Larousse as 'the most prolific historical painter in the second half of the 18th century' (tr.).

9 Louis, Duke of Burgundy, died in 1761.

10 The Dauphine, Marie-Josèphe de Saxe, died in 1767.

11 Jacques Chouillet, La Formation des idées esthétiques de Diderot 1745-1763 (Paris: Armand Colin, 1973) 23 (my translation).

12 Salon de 1767, XI, 72. See Horace, The Art of Poetry 1. 289 (reference given by Diderot).

13 One among many faces of the fascination exercised by De Rerum Natura on writers of the Enlightenment was the suspicion that somehow Lucretius had solved their most basic problem: how to write on science and social issues and call the result literature. See the Encyclopédie article 'Poème didactique.'

14 More precisely, in his critique of Watelet's poem, Diderot quotes nine of the eleven Latin lines comprising the Venus-Mars passage, and translates them, with a few extra French lines from elsewhere in the Latin poem to form a context. He quotes all eleven Latin lines, and retranslates, in the 1767 Salon.

15 M.L.G. De la Grange, De La Nature des choses, traduction nouvelle, 2 vol. with Latin text and notes (Paris: np, 1768). An authoritative work used by French publishers into the twentieth century. For Diderot's involvement, see Baron Grimm's contemporary account: F.-M. Grimm, Correspondance littéraire... (Paris: Longchamps et Buisson, 1813) Part I, v. VI, 144-46.

16 That is, not in the section of the Salon concerning Le Dauphin mourant.

17 The Iphigenia passage is DRN I, 80-101. Some idea of Lucretius's place in the 18th-century fight against fanaticism can be had from knowing that the much-quoted line is invoked eleven times in Voltaire's letters (see A. Redshaw, 'Voltaire and Lucretius,' Studies on Voltaire 189, 22). The word commonly translated as 'superstition' is in Latin religio. 